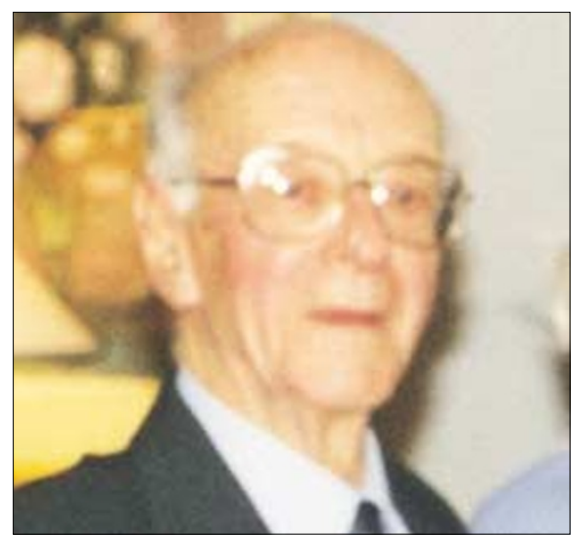

Maurice Poulter died peacefully after a short illness in Musgrove Park Hospital, Taunton on 6 January 2001 in his 90th year. Neville Maurice Poulter was born in Manchester on 3 September 1911 and spent his childhood there. He was the youngest of three boys and attended Manchester Grammar School. He then studied forestry at the University of North Wales in Bangor. However, he decided that forestry was not the career for him, and subsequently studied dentistry at the Turner Dental School in the University of Manchester and qualified LDS in 1937.

He worked for a short while in a practice in Barnsley before joining the then School Dental Service in Northampton. When the war came in 1939, Maurice was called up and served for the duration as a Dental Officer in the RAF. It was at Bangor that he first met his future wife Jane. They were married in 1938 and enjoyed over 62 years of marriage together. Incidently, to his wife and family he was always known as Neville.

After the war, the family moved to Somerset in 1947. Maurice joined the School Dental Service in that county at the same time as colleague Quinton Davies, and they worked together for some 25 years. The family was now growing, with a daughter Stephanie and a son Edward. In 1954, they moved to Taunton, which was to remain home for the rest of Maurice's life. Maurice soon developed an interest in orthodontics and undertook postgraduate training leading to the DDO qualification from Glasgow University in 1951. Orthodontics was to remain his passion in dentistry and he became a leading advocate and enthusiast in this sphere. He often likened orthodontics with forestry, in that one is working with the forces of nature to improve appearance and function in the mouth or the forest.

There are many generations of young people in Somerset from the early 1950's to the mid 1970's who will forever be grateful to Maurice for orthodontic advice and care. He was involved in setting up a cleft palate clinic at Taunton Musgrove Park Hospital, where he became involved with fitting an acrylic prosthesis soon after a baby's birth to enable the child to feed properly. Maurice worked in close liaison with the first Orthodontic Consultant in Taunton, Malcolm Brenchley, until his retirement. It was the start of an integrated service between the hospital and community, which served as a model for others.

Maurice took a particular interest in postgraduate activities and was Chairman of the Bristol Orthodontic Study Group for several years. His active involvement did much to improve co-operation between dental colleagues in practice, the community and hospitals in the south west. Maurice was a well organised and trusted colleague. In the 1960's, he efficiently and effectively chaired the Whitley Council Staff Side, which was concerned with pay and conditions for staff in the public dental services. He was a wise man, who would listen to all views and then strongly support the considered course of action, even if it was not always popular. Many of us have reason to be grateful to Maurice for his support and friendship over the years.

After Maurice retired from dentistry in 1973, he enjoyed a long and happy retirement with Jane in Taunton. Maurice always enjoyed his holidays and was never happier than when walking in the Somerset hills and forests. He was also a dedicated family man. Maurice will be sadly missed by all of us who were privileged to know and work with him, especially his wife and family.

J. D. P.

\title{
Stanley Ernest Charman MBE
}

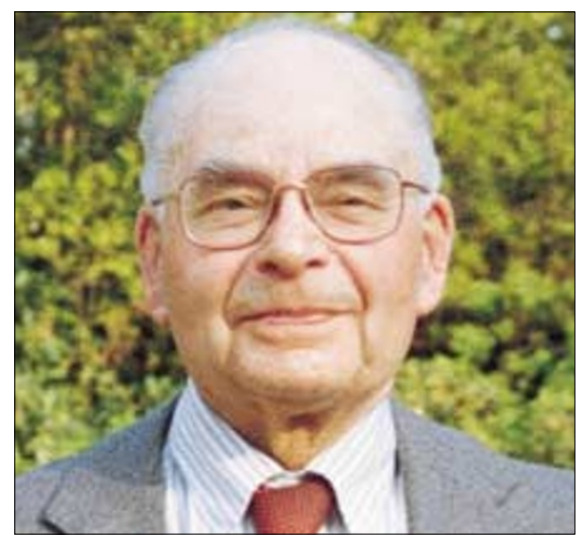

When Stanley Charman died on December 292000 in his 95th year, the dental profession lost someone who was the epitome of the professional man of his generation. During his professional life he was rarely to be seen out and about without his bowler hat (or latterly his trilby), always immaculate, dignified, hungry for knowledge but ever humble, always prepared to offer a helping hand and always interested in people, whatever their walk in life.

Stanley was born in Brighton where, in his youth, he was a very keen fisherman and loved nothing better than the cut and thrust of political debate. His dental career started in London where he qualified in 1931. He wasted no time in joining the British Dental Association and was a member for 69 years, a record which surely has seldom been broken or even equalled. Soon after he qualified, he went on holiday to the Channel Islands where he met Peggy, a meeting which blossomed into marriage in Westminster Cathedral in August 1935, a marriage which was to last until his death 65 years later.

Stanley's life can be summed up as one of service. Service to his country in the Royal Air Force from 1940-1945 where, in 1943, he was awarded a certificate of good ser- vice, to be followed in 1945 by an MBE Service to his profession in his dedication to his patients, especially in the General Dental Services in Eastleigh, and to his colleagues. The offices that he held over many years are too many to catalogue but among them were: secretary of the London Hospital Dental Society, chairman of the Southampton and District Section and president of the Wessex Branch of the BDA. It was not surprising that, to mark his outstanding contributions to the dental profession and the Association, he was elected to Life Membership in 1980. Though Stanley loved his profession he had other interests. He was a keen and knowledgeable photographer and loved his cars, a love that was second only to that for Peggy to whom we extend our sympathy. A long innings well played.

T. C. 